\title{
Scientists of the Gwansang-gam, the Royal Observatory of Joseon Dynasty (1)
}

\author{
Il-Seong $\mathrm{Nha}^{1 \dagger}$, Sarah $\mathrm{Nha}^{2}$, and Haman $\mathrm{Cho}^{3}$ \\ ${ }^{1}$ Yonsei University Obsevatory, Yonsei University, Seoul 120-749, Korea \\ ${ }^{2}$ Korean Science and Culture Agency, Yecheon, Kyeongbuk 757-910, Korea \\ ${ }^{3}$ Korean Academy of Meteorology and Climate, Seoul 156-720, Korea
}

We have uncovered 14 Korean royal astronomers and one scientist who worked in the early and mid-18th century. In spite of their high positions in the government office, all of them but one were not recorded anywhere in the major histories, such as WangjoSillok (王朝實錄) and JeungboMunheonBigo (增補文獻備考). Our search of Bon'gwans for each person has been carried successfully for 13 scientists. Their family relations are also uncovered finding five eminent astronomy families.

Keywords: Bon'gwan (本貫), genealogy, Gwansang-gam, Gwansang-gam Jeong, SeongbyeonDeungrok, Shihxian-shu, Yi Se- $\square$

\section{INTRODUCTION}

In Joseon dynasty (1392-1910) were there many distinguished scientists. Yet today's science-historians in Korea have had been worked for their works and lives of very limited well known scholars only, around or slightly more than a dozen in number. It is quite true that these small number would not represent all the achievements which were made during the period, particularly, of the 15th through 18th centuries in the Korean history of astronomy. In order to understand the highlights of science in Joseon fully, the time has fortunately been riped for the search of those neglected majority scientists who devoted their lives behind-the-scenes.

However, their names are far behind of our reach because of the poor records in the Korean histories. This situation may be analogues with the statement of W. Carl Rufus (Rufus 1936) who lived in Korea for ten years, 1907-1917.

"Looking for survivals of ancient Korean astronomy is like searching for the claws of the dragon."

The searching of manpower plays important part of infrastructure in the study of history of astronomy in Korea. We have been searched names of scientists with materials not only the major Korean histories but also the documents which had been relatively ignored by the present-day science-historians. In this line of efforts over the period of last decades, we have uncovered more than 500 names of scientists, mainly astronomers, who were belonged to the Gwansan-gam (觀象監), the Royal Observatory of Joseon. These names had been listed according to the hangul order together with their family backgrounds and works. This list, tentatively named as $A$ List of Korean Scientists, has led us to pay attention to a few interesting topics. Among which we have noticed one thing that there are many groups of similar names which may be accounted as to represent the members of same families. A total of 22 groups with three and more similar names with common surnames are found in our list. Among these we choose a group of 11 names, all of which has “Yi (李) Se (世)- $\square$ ” in common with only the last character $\square$ different. In this case the first character 李 represents surname, the 世 common name for brothers and/or cousins if they belong to a same family and the last $\square$ for individual person, respectively. All of them lived in the essentially same period of time, the early and mid-18th century. This was the time when there were in the intensive interactions and exchanges with Qing (清) astronomers.

This work is to identify 11 names whether they belong to a same family or not. While searching their names in each (c) This is an open Access article distributed under the terms of the Creative Commons Attribution Non-Commercial License (http:// creativecommons.org/licenses/by-nc/3.0/) which premits unrestricted non-commercial use, distribution, and reproduction in any medium, provided the original work is properly cited.
Received Dec 28, 2012 Revised Jan 17, 2013 Accepted Jan 21, 2013 †Corresponding Author

E-mail: slisnha@chol.com

Tel: +82-2-337-9650, Fax: +82-2-333-9650 
genealogy one was dropped out and five more names have been found. We present these 15 scientists in total with their family background and achievements.

\section{THE COMMONNAMEYISE- $\square$}

A total of 11 names with Yi Se- in common has been listed according to hangul order not English alphabetical, and they are as follows:

Yi Se-gyu (李世圭), Yi Se-beon (李世蕃), Yi Se-byeong (李 世炳), Yi Se-wui (李世煒), Yi Se-yoon (李世潤), Yi Se-ju (李 世胄), Yi Se-jing (李世澄), Yi Se-tae (李世泰),Yi Se-hyeung (李世衡), Yi Se-whan (李世煥) and Yi Se-heup (李世洽).

These are all astronomers who lived in the early and mid-18th century except one Yi Se-hyeung (李世衡). Our preliminary investigation has uncovered that this Yi Se-hyeung was lived in the reign period of King Sejong who was about 300 years prior to others. And, therefore, the remaining ten names became our object of further investigation.

As is well known fact that Yi is the one of the most populated names in Korea, we have to survey 16 different Bon'gwan (本貫)s which have Yi as their surname in common. Our very first attempt for their Bon'gwans was started with two major histories, WangjoSilloks and JeungboMunheonBigo, without success.

Our second attempt was then to consult with an encyclopedia HankukMinjokMunwhaDaebaek'guaSajeon (韓國民族文化大百科辭典). In this encyclopedia only one name Yi Se-tae (李世泰) was registered, but he was either an astronomer nor scientist in the introduction of his life in this encyclopedia (HankukJeongsinMunwhaYeon'guwon 1991). This means that he must be a different person with the same name.

Our third attempt was fortunately successful in finding some of other members. This was done by the consulting with the HankukYeokdaeInmulJonghapJeongboSystem, which was edited using mainly information in the Joseon Sidae Japgua Hapgyeokja Chongram (朝鮮時代雜科合格 者總攬), JapguaBangmok (雜科榜目) (cited 2012 Nov 15, available from http://people.aks.ac.kr). As a result of this search we have successfully collected Bon'gwans for 8 members.

Our last attempt, the most laborous and time consuming process, was to check and confirm their names in each Yi genealogy, Jokbo (族譜) of Yi (李氏). The biggest difficulty was the encounter with the genealogy of Kyeongju Yi (慶州 李氏). The number of population which belongs to this Yi family is so large that the family itself has 21 independent
Table 1. Ten and five additional names of astronomers with their Bon'gwans.

\begin{tabular}{|c|c|c|c|}
\hline No. & Name & Bon'gwan (本貫) & Family relationship \\
\hline 01 & YiSe-gyu李世圭 & Ansan (安山) & \multirow{3}{*}{ Brothers } \\
\hline 02 & Yi Se-ju 李世胄 & Ansan (安山) & \\
\hline 03 & Yi Se-byeong 李世炳 & Haum (河陰) & \\
\hline 04 & Yi Se-wui 李世煒 & Haum (河陰) & \multirow{2}{*}{$\begin{array}{l}\text { Son (Se-wui) and father } \\
\text { (Koo) }\end{array}$} \\
\hline 05 & Yi Koo 李絿 & Haum (河陰) & \\
\hline 06 & Yi Se-heup 李世洽 & Yangseong(陽城) & \multirow{3}{*}{$\begin{array}{l}\text { Son(Se-heup), } \\
\text { Father(Yang-jeok) and } \\
\text { Grandfather(Gye-heung) }\end{array}$} \\
\hline 07 & YiYang-jeok李陽迪 & Yangseong(陽城) & \\
\hline 08 & YiGye-heung李繼興 & Yangseong(陽城) & \\
\hline 09 & Yi Se-beon李世蕃 & Kyeongju (慶州) & \multirow{3}{*}{$\begin{array}{l}\text { Grandson (Se-beon) and } \\
\text { Grandfather (Gyeong-wha) }\end{array}$} \\
\hline 10 & YiGyeong-wha李慶華 & Kyeongju (慶州) & \\
\hline & Yi Se-jing 李世澄 & Youngcheon(永川) & \\
\hline 12 & YiSe-whan 李世煥 & Yeoju (摡州) & \multirow{4}{*}{$\begin{array}{l}\text { Cousins(?).Theircommonname } \\
\text { is } \square \text {-whan, not Se- } \square \text {. }\end{array}$} \\
\hline 13 & Yi Joong-whan 李重煥 & Yeoju (荋州) & \\
\hline & Yi Se-yoon 李世潤 & Unknown & \\
\hline 15 & Yi Se-tae 李世泰 & Unknown & \\
\hline
\end{tabular}

branches (派). Each branch has many generations (世 孫) since its origin ranging over 30 , and thus this made us in a great confusion which generation is equivalent to the early and mid-18th century of our interest. One of the most difficult case was the name Yi Se-beon (李世蕃) as an example. This name is enlisted in 5 different branches among 21; a 21st generation (世孫) for Sain branch (舍人 公派), a 22nd generation for Pyeongri branch (評理公派), a 23rd and a 28th generations each for Kukdang branch (菊 堂公派), a 28th generation for Sangseo branch (向書公派) and a 30th generation for Bujeong branch (副正公派). This means that there are 6 Yi Se-beon (李世蕃)s in five different branches.

Overcoming many other difficulties we have found five additional astronomers at the end. These five new entries are all family relations with ten astronomers as either father, grandfather, great-grandfather or cousin. Let us now list these 15 names in Table 1.

\section{BRIEF INFORMATION FOR EACH ASTRONOMERS}

We have now reached to our goal to investigate personal information of each of ten astronomers even though their family background and life are poorly known.

\subsection{Yi Se-ju (李世胄)}

Se-ju's Bon'gwan (本貫) is Ansan (安山) and his childhood name (子) was Gongseo (公瑞). He was born in 1676, the 2nd year of King Sookjong's reign period, but his death is not known. 
Se-ju's precedents were high ranking officers in the government. His father Yi Sang-baik (李佾白) was JeolchoongJang'goon (折衝將軍, 正三品堂上官), grandfather Yi Bin-gweon (李贇權) Sagua (司果, 正六 品官) and great-grandfather Yi Seong-bok (李聖福) HeminseoJooboo (惠民署主簿, 從六品官), respectively. His mother's grandfather Kim Hoo-rip (金後立) was also known as a high ranking officer, named CheomJeoljesa (薟節制使). His wife's family, on the other hand, was mainly belonged to the Department of Foreign Language Translations. His father-in-law HyeonGak (玄玨) was a high ranking officer at the Foreign Laguage Department Sayeok-won (司譯院正, 正三品堂下官), grandfather-in-law Hyeon Deok-woo (玄 德宇) was ranked GauiDaeboo (嘉義大夫, 從二品官堂上官, 東班) and great-grandfather-in-law HyeonSeok (玄碩) was ranked TongjeongDaeboo (通政大夫, 正三品堂上官, 東班). Se-ju had a younger brother Se-gyu (世圭) who was also an astronomer.

Se-ju had passed a state examination Siknyeon-si (式 年試) when he was 38 in the 40th year of King Sookjong's reign period (1714). His positions after this examination stepped up rapidly to the Calender Computer (三曆官), Professor (敎授, 從六品官) and finally to the Guansang-gam Jeong (正, 正三品堂下官). His astronomical achievements

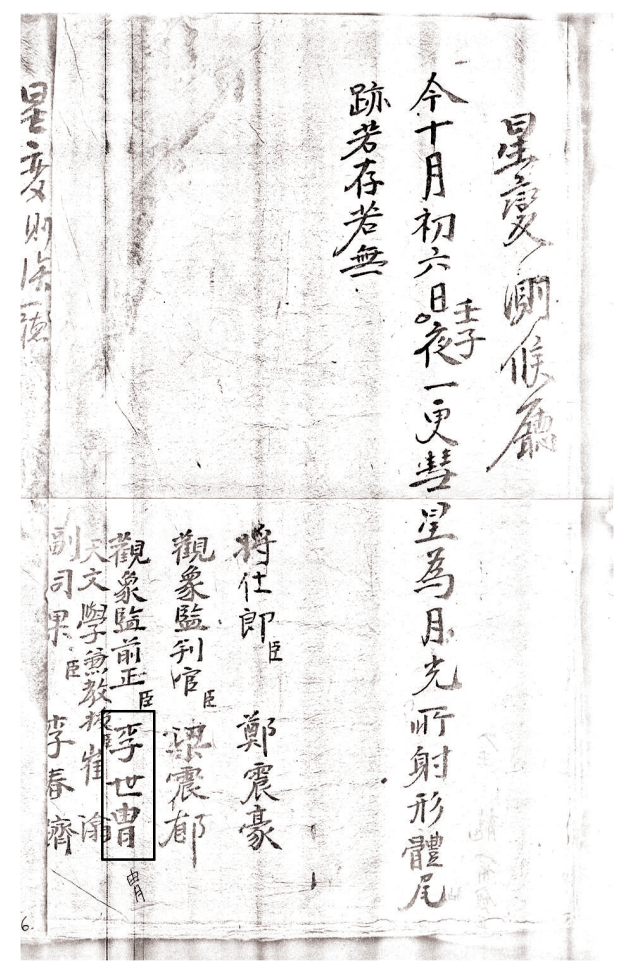

Fig. 1. A comet record on the sixth day of the tenth month of the 1723 SeongbyeonDeungrok. Yi Se-ju's name (李世胄) is in the third from right among five observers (Courtesy of Yonsei University Library). are found in two documents. The first one is the 1723 SeongbyeonShookhooDanja (星變測候單子) (see Fig. 1), which is the observation report of a comet (Gwansang-gam 1723). He was 47 years old when he joined the observation as an officer Jikjang (直長, 從七品官) by then. The second is the Calender of the 28th year of King Yeongjo (英祖 28, Gwansang-gam 1725) (see Fig. 2). This was the year when he was 76 years old and by then his position was advanced to the OemoJang'goonHaengchoongmuwuiBusajeong (禦侮將軍 行忠武衛副司正, 從二品官). It is, thus, easy for us to assume that his position in the government was very high and had lived long life as an astronomer. With only these two uncovered records limit our search for his long and active engagements at the Royal Observatory, but it would possible us to claim that he was really an active worker in the fields of astronomical observations and of calendar makings in the early and mid-18th century.

\subsection{Yi Se-gyu (李世主)}

Se-gyu's Bon'gwan (本貫) is also Ansan (安山) as his elder brother Se-ju, but either his childhood name nor his years of birth and death are not known. His family members in a direct line should be the same as those of his brother

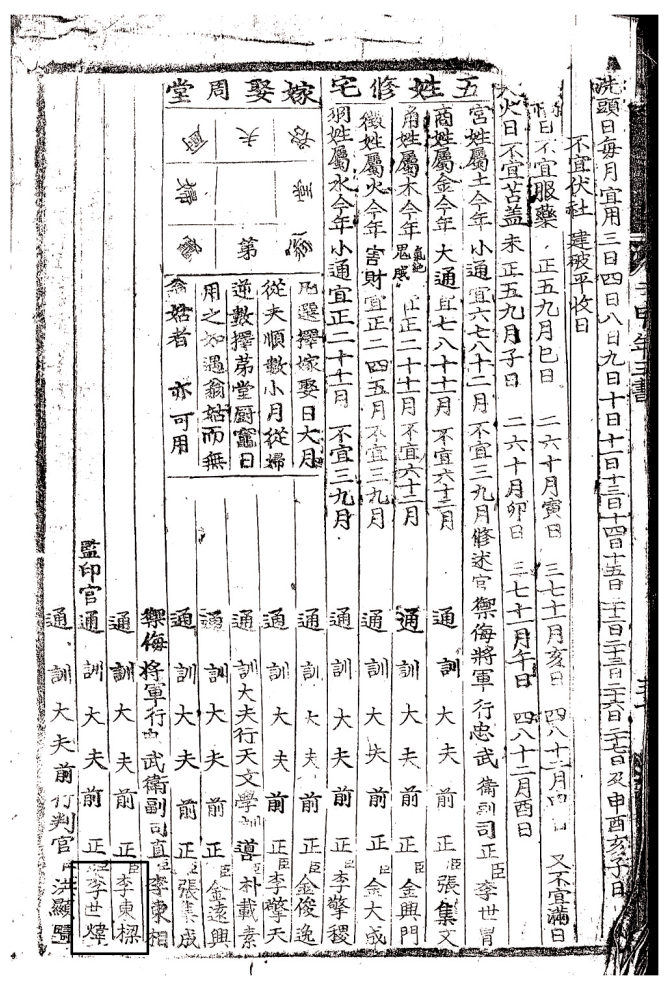

Fig. 2. The last page of the Calender of the 28th reign year of King Yeongjo (1752) has two names of calender computer, Yi Se-ju (李世甾) and Yi Se-wui (李世煒) (Adopted from Nha Il-Seong). 
Se-ju. His wife's family, on the other hand, also seemed high ranking officers in the government. His father-in-law Bak Choong-geon (朴忠健) was Dongji (同知) and grandfatherin-law Bak Mook-seon (朴墨善) ranked to Gaseondaeboo (嘉 善大夫, 從二品官堂上官, 東班).

Se-gyu had passed a state examination Siknyeon-si (式年 試) in the 40th year of King Sookjong (1714), which was the same year as the case of his brother. His positions after this examination stepped up rapidly to the Calender Computer (三曆官), Professor (敎授, 從六品官) and finally to the Guansang-gam Jeong (正, 正三品堂下官) as his brother.

However, Se-gyu's achievement is poorly known leaving us only one record in the 1723 SeongbyeonDeungrok (Gwansang-gam 1723) as an observer (see Fig. 3).

\subsection{YiSe-byeong (李世炳)}

Se-byeong's Bon'gwan (本貫) is Haum (河陰). He was born in the 22nd year of King Sookjong's reign period (1696), but his death is not known.

His father Yi Hyeon (李絢) was a high ranking military officer Ho'goon (護軍, 三品官) and no other information on his family is available at this stage of investigation.

Se-byeong had passed a state examination Siknyeon-si (式年試) in the 40th year of King Sookjong (1714), which is accidentally coincident with the year of Se-ju and Se-gyu mentioned previously. Only difference from other two is the age. Se-byeong was very young, only 19 years old.

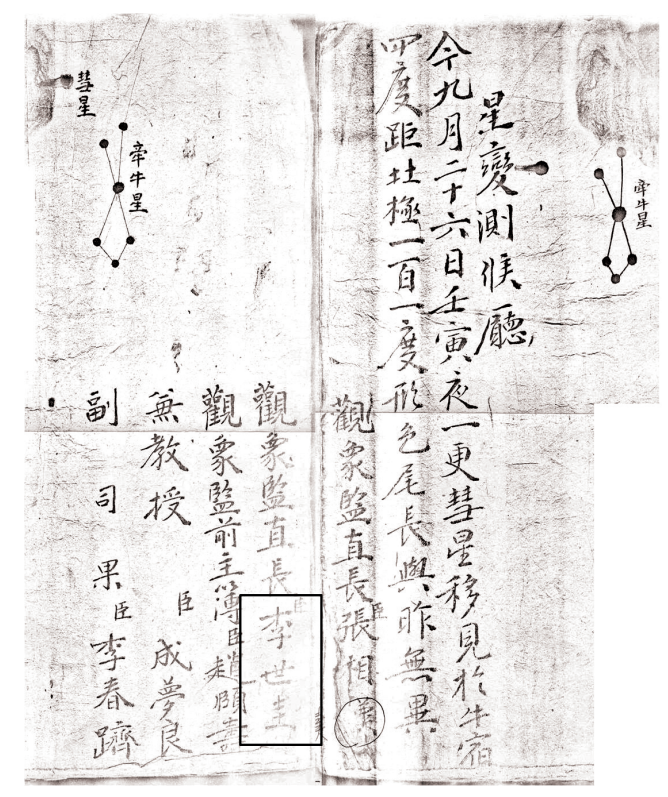

Fig. 3. A comet record on the twenty sixth day of the ninth month of the 1723 SeongbyeonDeungrok. Yi Se-gyu's name (李世圭) is seen barely in the second from right among five observers (Courtesy of Yonsei University Library).
Se-byeong has left us his name as an observer of the 1723 Comet (Gwansang-gam 1723). This was made 9 years after his passage of the examination in 1714. But his position at the Royal Observatory was Jangsarang (將仕郎), low position compare to other two (see Fig. 4). This does not, however, discourage us if we regard with his very young age of only 28 by then.

\subsection{Yi Se-wui (李世煒)}

Se-wui's Bon'gwan (本貫) is Haum (河陰). He was born in the 35th year of King Sookjong's reign period (1709), but his death is not known.

Se-wui's father Yi Koo (李絿) had passed his state examination in the section of mathematics, and advanced to the Gwansang-gam Jeong (觀象監正, 正三品 堂下官).

Koo had been engaged in the observations as an observer of the Gwansang-gam. There are two records, which support this claim. The first one is the 1723 SeongbyeonDeungrok (see Fig. 5) and the second in the list of observers participated

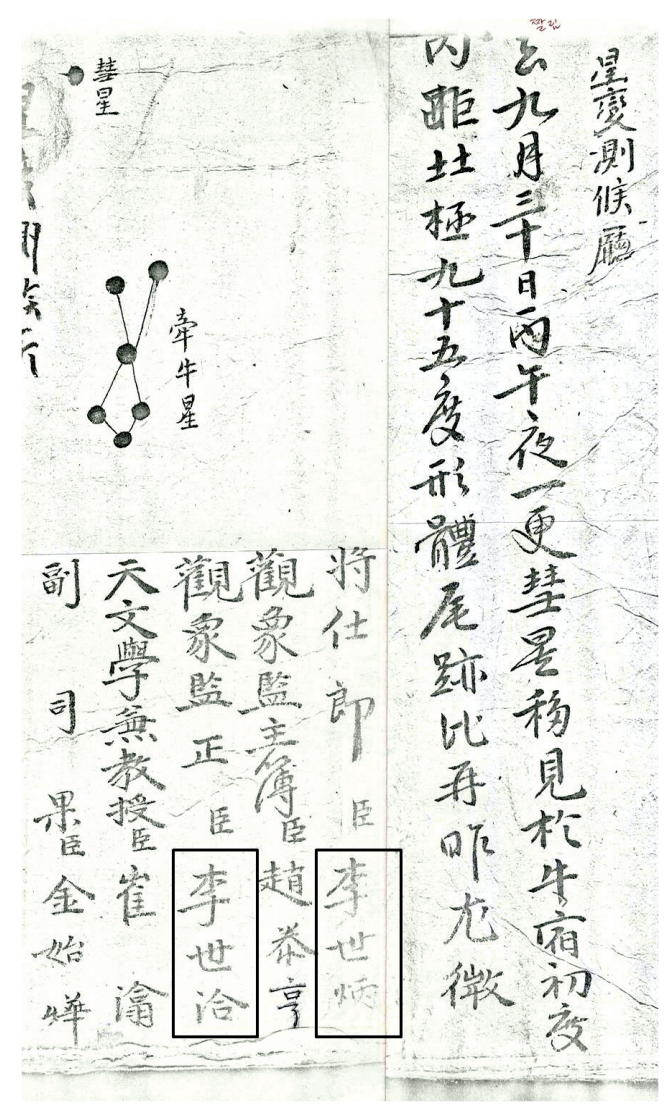

Fig. 4. A comet record on the thirtieth day of the ninth month of the 1723 SeongbyeonDeungrok. Two names, Yi Se-byeong (李世丙) and Yi Seheup (李世洽), are seen in the first and the third from right among five observers (Courtesy of Yonsei University Library). 


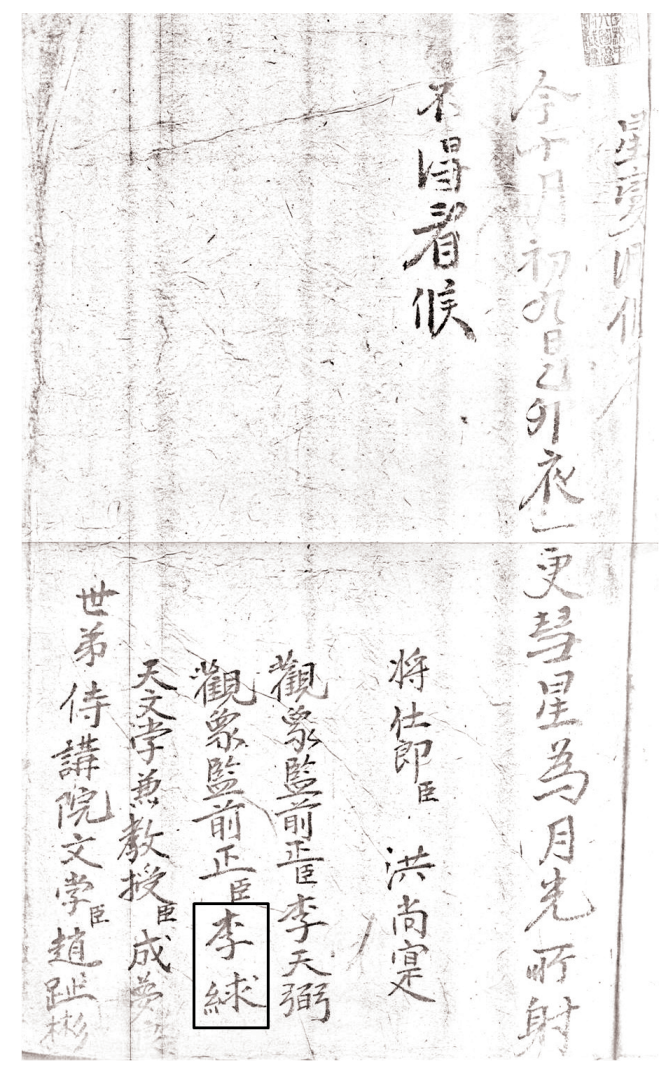

Fig. 5. A comet record on the ninth day of the tenth month of the 1723 SeongbyeonDeungrok. Yi Koo (李絿), father of Yi Se-wui (李世煒), is seen in the third from right among five observers (Courtesy of Yonsei University Library).

of this comet at the end of the Deungrok (Gwansang-gam 1723). Se-wui's maternal grandfather Han Gui-seong (韓貴 成) was Cheomji (薟知, 從四品官). Se-wui's wife belonged to Haejoo (海州) Yi which is an another Bon'gwan (本 貫) in Korea. His father-in-law was Yi Se-choo (李世樞), grandfather-in-law Yi Bal-yeon (李浡然) was an officer at the Department of Foreign Language Translations (司譯院 正, 正三品堂下官) and great-grandfather-in-law Yi Seungyeong (李承英) was JeolchoongJang'goon (折衝將軍, 正三品 堂上官).

Se-wui has had passed a state examination Siknyeon-si (式年試) in the 5th year of King Yeongjo (1729) at his age of 21. He had participated in the calendar making in the 28th year of King Yeongjo (see Fig. 2 above). He had also joined a group of the Halley's comet observers in the 35th year of King Yeongjo for two nights, on the sixteenth day (see Fig. 6) and on the twenty eighth day of the third month. By these two records we can claim him that he was both an observer and a calendar maker at the Royal Observatory and a member of a two generation astronomer family after his father.

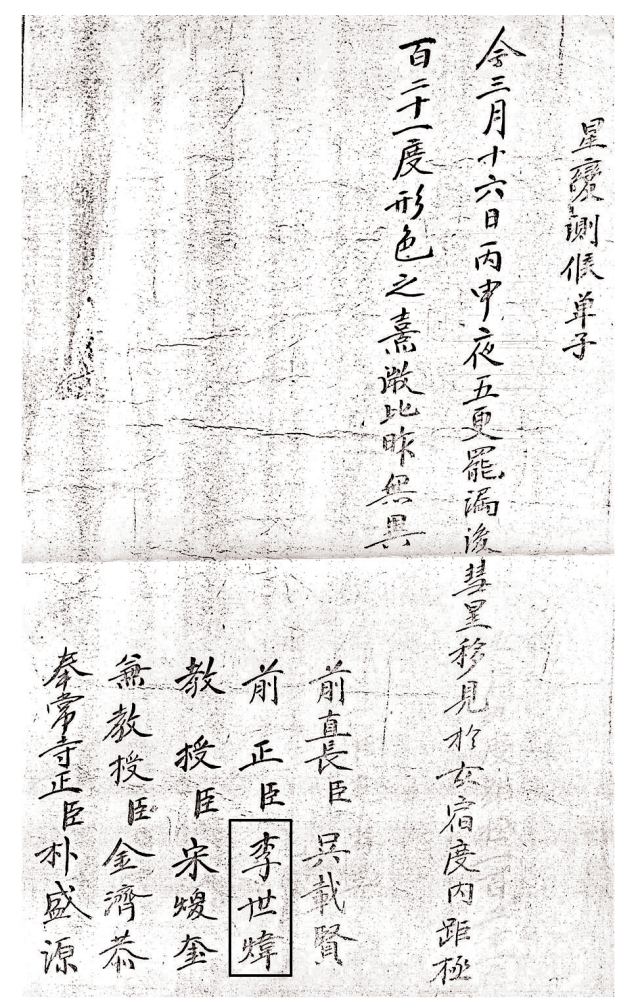

Fig. 6. A comet record on the sixteenth day of the third month of the 1759 SeongbyeonDeungrok. Yi Se-wui (李世煒), a son of Yi Koo (李絿), had succeeded the comet observation 36 years after his father (Courtesy of Yonsei University Library).

\subsection{Yi Se-beon (李世蕃)}

According to the HankukYeokdaeInmulJonghapJeongb o System, Se-beon's Bon'gwan is Kyeongju (慶州) and his childhood name was Goon'sil (君實) (cited 2012 Nov 21, available from http://people.aks.ac.kr/index/aks). He was born in the 22nd year of King Injo (1644) but his death is not known. His father Yi Yi-gwan (李牘觀) was Gesa (計 士, 從八品官) and grandfather Yi-Man-ryeong (李萬齡) was a military officer Choong'ikWuijang (忠翊衛將). Sebeon's great-grandfather Yi Kyeong-wha (李慶華) was a mathematician at the Royal Observatory and hold once a position Joohak Professor (籌學教授, 從六品官).

Se-beon has had passed a state examination Joohak (籌學) in the 18th year of King Sookjong (1692) at his age of 49. His true family root is, however, remains suspicious as already introduced in the Section 2 above. The most plausible assumption, which we can make at this moment, is that he could be a 30th generation of Boojeong branch (副正公派). In this argument the information in the HankukYeokdaeIn mulJonghapJeongbo System is quite uncertain and supplies many confusions.

Se-beon had left us one record which was made in the 
3rd year of King Kyeongjong (Gwansang-gam, 1723) when he was at the position of the former Pangwan (前判官從五品官) of the Royal Observatory.

\subsection{Yi Se-jing (李世澄)}

Se-jing's Bon'gwan (本貫) is Yeongcheon (永川) and was born in the 27th year of King Sookjong (1701) but his death unknown.

Se-jing's father Yi Han-sang (李漢相) had a government position Bu-sa'gua (副司果) and no other members of his family are known.

The year when Se-jing passed a state examination Siknyeon-si (式年試) was the 6th year of King Yeongjo (1730) at his age of 30. Although not much information on his family is known, his astronomical achievements has been uncovered from four independent sources.

Se-jing's first contribution to astronomy was the 1723 Comet observation in the 3rd year of King Kyeongjong (Gwansang-gam 1723). This was made when he was retired a position Gwansang-gam Jeong (觀象監正, 三品官堂下) (see Fig. 7). His second contribution was a remarkable to astronomy in Joseon. That was the import of a complete set of LixiangKaocheng (曆象考成眞本全秩) in the 6th year of King Yeongjo when he went to Beijing as a member of convoy (Seungjeongwon Ilgi 1730). For this effort of the import he was rewarded by the king (Seungjeongwon Ilgi 1730). In the 8th year of King Yeongjo he also imported a Revised Chinese calender, so called Wannian-li (改正萬年曆), from Beijing. And then again he had imported New Wannian-li (萬年曆 新本) with many other science books (Seungjeongwon Ilgi 1732, YeongjoSillok 1732). This indicates that he was sent to China frequently by the Royal Observatory.

\subsection{Yi Se-whan (李世煥)}

Se-whan's Bon'gwan (本貫) is Yeoju (驪州) and his childhood name (子) was Yeowha (汝華). He was born in the 6th year of King Sookjong's reign period (1680), but his death is not known. His home town was Kwangju (廣州) near Seoul.

Se-whan belongs to the Sajik branch (司直公派) of Yeoju Yi (驪州李氏) and a 22nd generation (世孫) of this branch. This branch is famous in Korea because of a great Silhak (實學) scholar Seongho (星湖). Se-whan's father was Yi Bok-hyeu (李復休), and was a high ranking officer in the government TonghoonDaeboo (通訓大夫, 正三品堂下官東 班) but seems not related to the Royal Observatory.

Se-whan had passed a state examination Siknyeon-si (式 年試) in the 39th year of King Sookjong (1713) at his age of

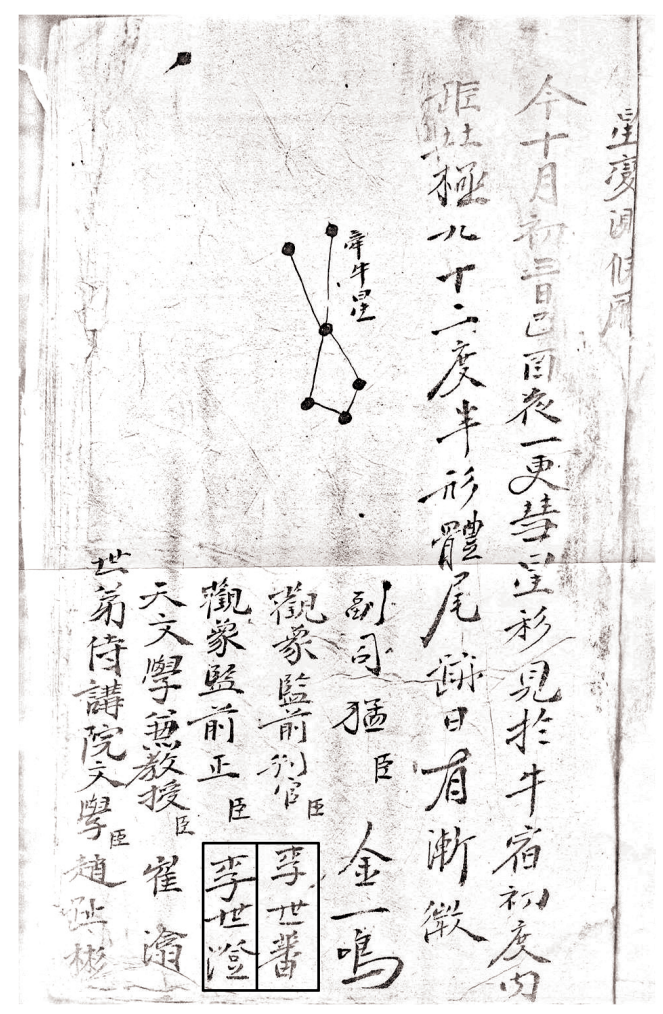

Fig. 7. A comet record on the third day of the tenth month of the 1723 SeongbyeonDeungrok. Two names, Yi Se-beon (李世蕃) and Yi Se-jing (李 世澄), are seen side by side (Courtesy of Yonsei University Library).

34. As an observer Se-whan had engaged in the observation of the 1723 Comet for two nights (see Fig. 8). He was then at the position of Jangsarang (將仕郎), which is rather low ranking at the Royal Observatory.

It is interesting to know at this point that not like others Se-whan's common name HangryeolJa (行列字) is not Se- $\square$ but $\square$-whan instead. Se-whan had a close relative named Joong-whan (重煥) who was 21st generation (世孫) of the same branch. This Joong-whan is now known as a famous geographer in the 18th century. His major work is a publication of a geographical book, Taekri-ji (擇里誌).

Se-whan had two brothers Jo-whan (朝煥) and Jeongwhan (廷煥), but no information for them are available.

\subsection{Yi Se-heup (李世洽)}

Se-heup's Bon'gwan (本貫) is Yangseong (陽城) and he was a 18th generation of SamsiJoongpa branch (三侍中派). He was born in the 20th year of King Sookjong's reign period (1694), but his death is not known.

Se-heup's father Yi Yang-jeok (李陽迪) and his grandfather Yi Gye-heung (李繼興) were both high ranking 

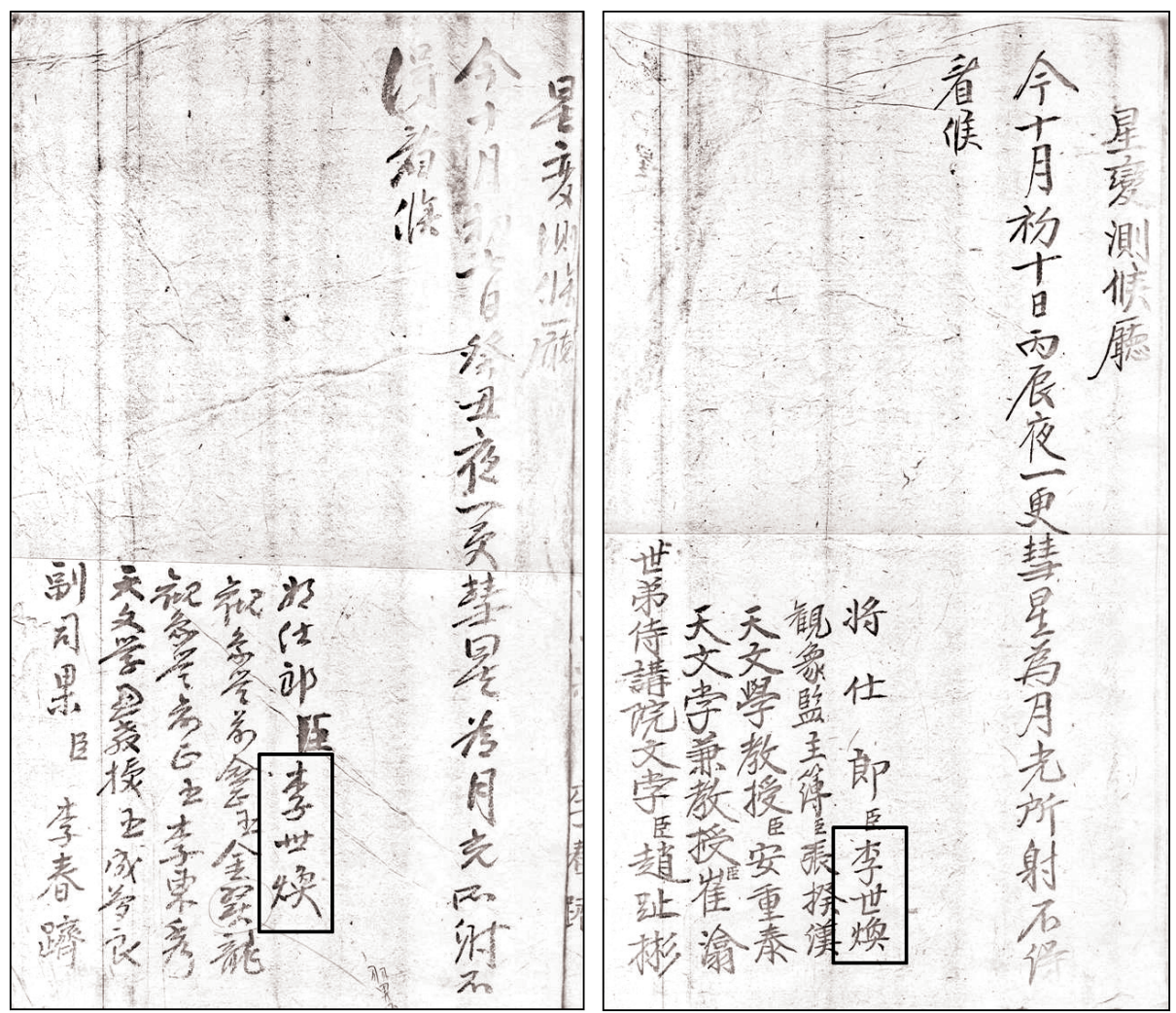

Fig. 8. Two comet records on the seventh and the tenth days of the tenth month of the 1723 SeongbyeonDeungrok. Yi Se-whan (李世煥)'s name is seen on both days (Courtesy of Yonsei University Library).

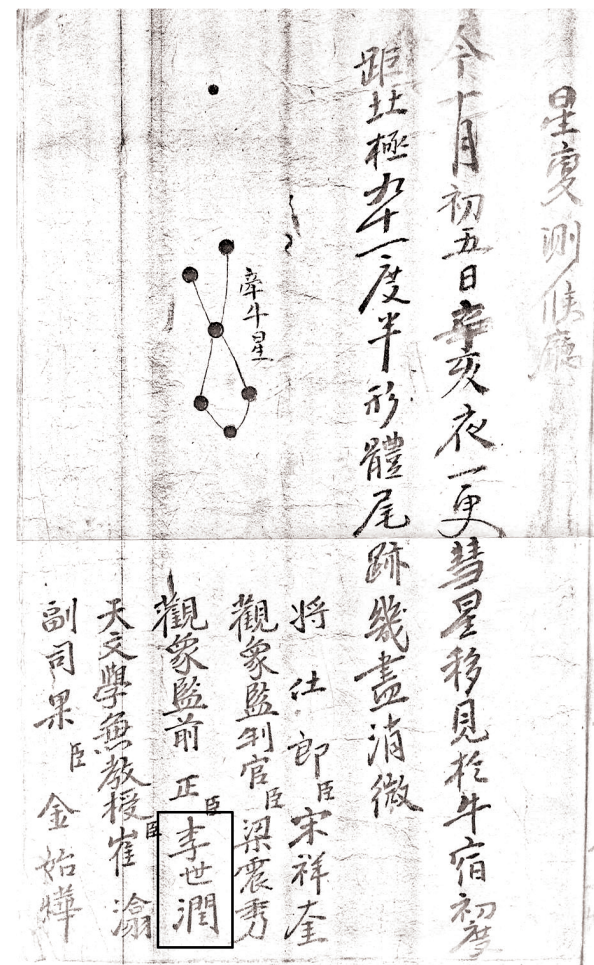

Fig. 9. A comet record on the fifth day of the tenth month of the 1723 SeongbyeonDeungrok. Yi Se-yoon (李世潤)'s name is seen on the third position from right (Courtesy of Yonsei University Library). officers at the Royal Observatory as a Gwansang-gam Jeong (觀象監正). This family is rare case that produced astronomers of three consecutive generations, and known as a famous astronomy family. His father-in-law Yi Jinbaek (李震白), on the other hand, was also an officer of the government of unknown department.

Se-heup had passed a state examination Siknyeon-si (式 年試) first on the list (壯元) in the 39th year of King Sookjong (1713) at his age 20. Ten years after his passage of this examination his comet observation was made in the 3rd year of King Kyeongjong in 1723 (see Fig. 4). His positions at the Royal Observatory were successively stepped up from the calendar maker (三曆官), Professor (從六品官), Kooim (久任) and finally Gwansang-gam Jeong (觀象監正, 正三品官).

\subsection{Yi Se-yoon (李世潤)}

We have a slightest information about his life including even his Bon'gwan (本貫). If he did not, indeed, leave us his names three times in the 1723 SeongbyeonDeungrok for the 1723 Comet (see Fig. 9), his name as an astronomer would have been veiled forever. He had possessed a high position Gwansang-gam Jeong (觀象監正) at the Royal Observatory by that time. 


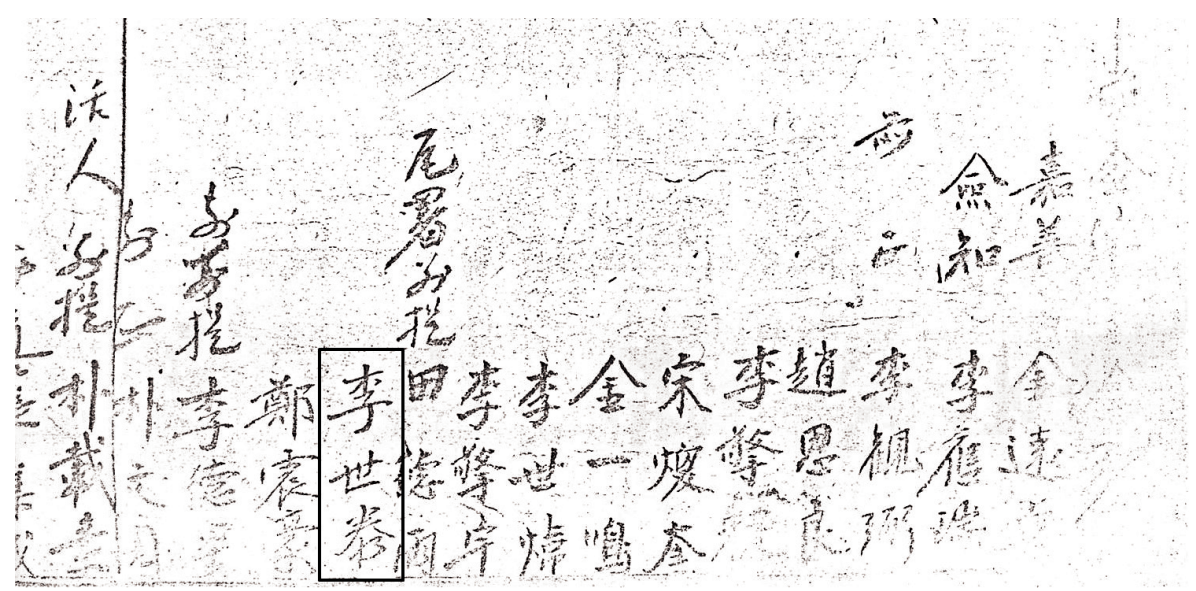

Fig. 10. Among many observers involved in the 1760 Comet Yi Se-tae(李世泰)'s name is visible (Courtesy of Yonsei University Library).

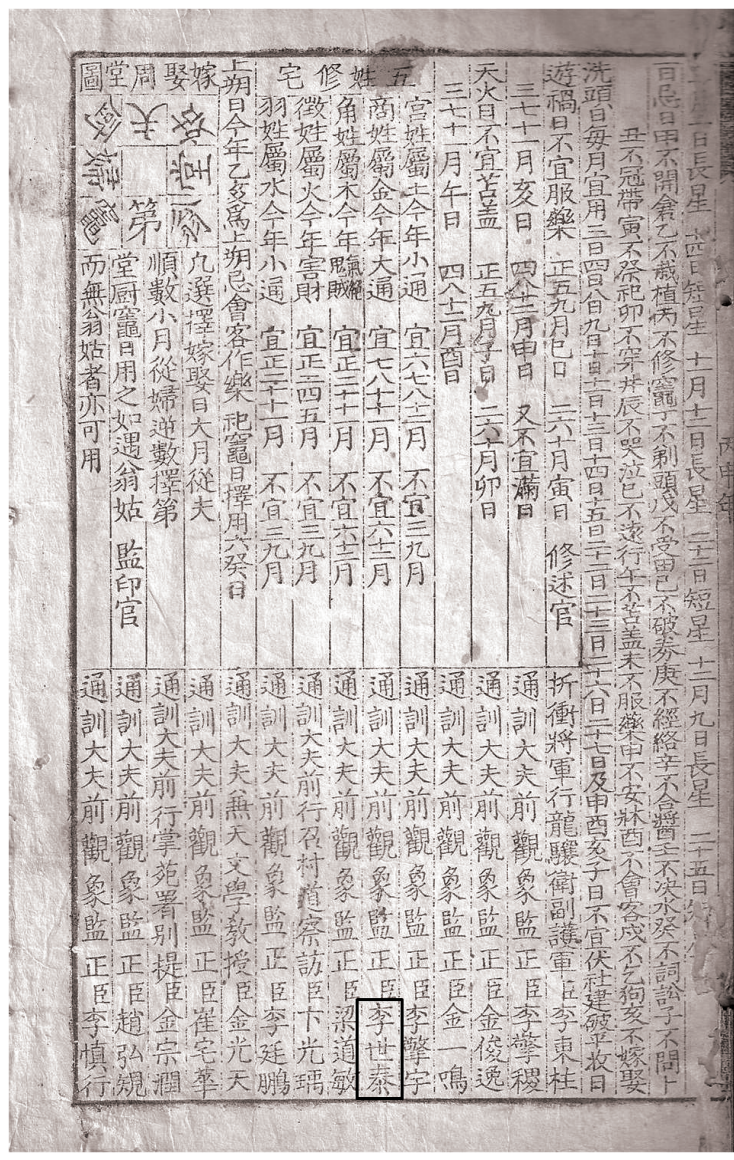

Fig. 11. A total of fourteen names of calendar computers are listed in the last page of the Calendar of the 52nd reign year of King Yeongjo (1776), in which Yi Se-tae (李世泰)'s name is in the sixth from right (Adopted from Nha ll-Seong).

\subsection{Yi Se-tae (李世泰)}

No information about Se-tae is available as the case of Seyoon above. Nevertheless, he left us two documents which states that he was a high ranking astronomer at the Royal Observatory. The first of these is the 1760 Comet Halley observation in the 35th year of King Yeongjo (see Fig. 10). His name was listed among many observers participated. This was on the 3rd day of the first month of the 35th year of King Yeongjo (1760), the last day of the series of observations. The second document is the 1776 calendar. By this time he was ranked TonghoonDaeboo Former Gwansang-gam Jeong (通訓 大夫前觀象監正). He should be remembered surely as both an observer and a calendar maker (see Fig. 11).

\section{CONCLUSIONS}

We have made a list of over 500 astronomers virtually unknown to us until now. Among them an intensive search of ten astronomers, who have common character Se (世) in their name, has been made. Even though they all have a character Se (世), it turned out they were not belonged under one same family but separated to at least six different Bon'gwan (本貫)s. They were, except only Se-jing (世澄), not at all recorded in the major histories in Korea. Although their profiles are edited with our very limited source at this moment, it is hoped that this work will become a milestone for the future biographical research of scientists, particularly astronomers, in Korea.

Aside from these ten astronomers, as a by-product of this investigations, we have uncovered additional five who are members of each of these ten members. These 15 astronomers are already given in Table 1 . We will now summarize several interesting new findings.

\subsection{Family relations}

Following information will be worth of mention. (1) Se- 
gyu (世圭) and Se-ju (世胃) are brothers and both were observers and calendar makers with high ranking position (Gwansang-gam Jeong, 觀象監正) at the Royal Observatory. (2) Se-wui (世煒) and Koo (絿) are son and father relation making an astronomy family of two generations, but father Koo's profile has not been made unfortunately. (3) Seheup (世洽), Yang-jeok (陽迪) and Gye-heung (繼興) made an astronomy family of three generations, which is very unusual case. This family will certainly attract particular interests in the future investigation. (4) Se-beon (世蕃)'s great-grandfather Kyeong-wha (慶華) was a mathematician at the Royal Observatory, but his father Yi-gwan (牘觀)'s position Gesa (計士, 從八品官) is difficult to characterize its profession whether it belongs to the Gwansang-gam or not by the present authors. (5) Se-whan (世煥) and Joong-whan (重煥) could be cousins, but not like other members they had a common character -whan (煥) for their names.

\subsection{Individuals}

(1) Se-byeong (世炳) had passed a state examination at his age of 19, whereas 49 years old for Se-beon (世蕃). (2) Seheup (世洽) had passed his state examination first on the list (壯元) at his very young age of 20. (3) Se-jing (世澄) seems very important person for the further investigation. Not like others he won the honor to be recorded in both Seungjeongwon Ilgi (承政院日記) and YeongjoSillok (英祖實錄). We will, thus, strongly recommend to other investigators to search his life. (4) We are in deep sorrow for the fact that our searching was very limited regarding two eminent astronomers Se-yoon (世潤)and Se-tae (世泰), because of their Bon'gwan (本貫)s are not known.

This work has been started with only a limited number of astronomers with their family backgrounds and astronomical achievements. Yet, it is hoped that our effort will serve to open a way for the future work on biographical dictionary for historical astronomers in Korea.

\section{ACKNOWLEDGMENTS}

The authors wish to express our sincere appreciation to Mrs. Kim Myongju of Yonsei University Library and Mrs. Kang Hisook of Yonsei University Museum for their assistances in searching genealogies and making the scanning of documents.

This study was funded by the Korea Meteorological Administration Research and Development Program under Grant CATER 2012-7180 named "Study for Restoring Meteorological Records in GaksaDeungnok (Pyeongsn- do) and The Annals of Joseon Dynasty (Yehjong and Seongjong)" which is national assignments supported by Center for Atmospheric and Earthquake Research (CATER)'s to enhance climate change monitoring, forecast.

\section{REFERENCES}

Gwansang-gam, The 1723 SeongbyeonDeungrok (1723).

Gwansang-gam, The 1752 Calendar (大清乾隆十七年歲次 壬申內用三書) (1752).

HankukMinjokMunwhaDaebaek'guaSajeon 18 (HankukJeo ngsinMunwhaYeon'guwon, Seoul, 1991), 17-22.

Rufus WC, Astronomy in Korea, The Transactions of the Korea Branch of the Royal Asiatic Society, XXVI, 1-53 (1936).

Seungjeong-won Ilgi, National Institute of Korean Histroy, 38, 816 (1730).

Seungjeong-won Ilgi, National Institute of Korean Histroy, 42, 297 (1732).

YeongjoSillok, 31, 9ab (1732). 